\title{
NAGY LÁSZLÓ, A MAGYAR GYERMEKTANULMÁNYOZÁS „ATYJÁNAK" EMLÉKÉRE...
}

\author{
Pirka Veronika \\ az Eötvös Loránd Tudományegyetem Pedagógiai és Pszichológiai Karának \\ doktorandusz hallgatója \\ pirka.veronika@ppk.elte.hu
}

2012. június 25-én az Eötvös Loránd Tudományegyetem Neveléstudományi Intézete megkoszorúzta Nagy László sírját. „Ritka munkás, nagytehetségü, kiváló kezdeményezö szellem, nemes lélek, tiszta ember..." - írta Nagy Lászlóról munkatársa, Ballai Károly 1932-ben A Gyermek c. folyóiratban.

Nagy László Kisújszálláson született 1857. június 27-én, édesapja pedagógus, édesanyja birtokos családból származott. Az elemi iskolát Nagykőrösön végezte, középiskolai tanulmányait a budapesti református fögimnáziumban, ahol 1875-ben jeles érettségit tett. Egyetemi évei alatt geológusi kutatásokat végzett Budapesten és környékén, Dobsinán és Tibold-Darócon. Az egyetemi olvasókörben tartott elöadást a földrengésekről és okairól. Így indult el Nagy László tudományos munkássága. 1878-ban befejezte egyetemi tanulmányait, ezután rövid ideig a borsodi Bottlik családnál nevelősködött. 1879-80-ban a budapesti állami gyakorló fögimnáziumban, mint gyakorló tanító müködött, tanári diplomáját 1880-ban szerezte meg. A középiskolai tanári diploma megszerzése után a budapesti II. kerületi állami tanítóképző intézetbe került, ahol természettudományos tárgyakat és pedagógiát tanított. 1886-ban házasodott meg.

Kezdeményezésére jött létre a II. Országos és Egyetemes Tanügyi Kongresszus 1896-ban. A Magyar Tanítóképző Intézeti Tanárok Országos Egyesületének főtitkára lett 1899-ben, és a Magyar Tanitóképzö c. folyóirat főszerkesztöje.

A gyermektanulmányozás iránti első érdeklődése 1890-es években mutatkozott meg, első cikke e tárgyban 1895-ben jelent meg a Magyar Tanitóképzö-ben. Így vall róla: „Ez a cikk támasztotta fel tudományos érdeklődésemet a gyermektanulmány iránt. Ez időtől fogva a kérdés folyton izgatott. Kezdtem tanulmányozni, cikkeket írni s másokat is hasonló tanulmányokra rábírni. Új élethivatás alakult ki bennem.”

1906-ban megalapította A Magyar Gyermektanulmányi Társaságot, és lapjának, A Gyermeknek 1907-től föszerkesztője lett. 1908-ban már a VI. kerületi állami tanítónőképzőben tanított pedagógia tárgyakat. Itt szervezte meg a lélektani laboratóriumot, amely továbbképző központja lett a kísérleti pszichológiának és a gyermektanulmánynak. 1909-ben munkásságáért a tanítóképző tanárai aranytollal tüntették ki. 
1911-ben Nagy László vezetésével első alkalommal vesznek részt a magyar gyermektanulmányozók a brüsszeli első gyermektanulmányi kongresszuson. 1916-ban az Apponyi-kollégium kísérleti lélektani előadója. 1918-ban tanítóképző-intézeti szakfelügyelővé választották.

Munkájának sikerességéről tanúskodik, hogy A Magyar Gyermektanulmányi Társaságnak 1919-ben már 10 fiókköre volt, és a tagok száma 4000 fölé emelkedett. 1925-ben a Fővári Pedagógiai Szeminárium Lélektani Laboratóriumának vezetöje lett haláláig, 1931. február 25-ig.

Nagy Lászlónál a gyermekvédelem a gyermeki személyiség totális megismerését és fejlesztését jelentette. A gyermektanulmány területén a gyermek érdeklődésének, erkölcsi, érzelmi fejlődésének menetét, törvényszerüségeit tárta fel. A kutatási eredményei nemzetközi elismerést váltottak ki. Családi Kapcsoskönyvében a következők olvashatók: „A magyar gyermektanulmányozás megszervezéséhez nagy ambícióval fogott, úgy érezte, hogy élete eszményi célt kapott, amire régen vágyott. Ez időtől kezdve fö törekvése volt közpályáját, és hivatását tökéletesen betölteni...családjával békésen élni, mert szerinte ezek mind együtt járnak."

Müvei között említhetjük: Fejezetek a gyermekrajzok lélektanából, A gyermek érdeklödésének lélektana, Didaktika gyermekfejlödéstani alapon. 22 évig szerkesztette $A$ Gyermek c. folyóiratot.

Pedagógiai tevékenységéről így vall: „Kezdettől fogva a fö gondolat a pedagógiai müködésre, az ifjúságra való közvetlen hatásra fordítottam. Arra törekedtem, hogy az ifjúságban eszményiséget fejlesszek ki. Az eszméket szeretni tanítottam meg öket: a hazát és gyermeket szeretni. Negyven év alatt nagy gárdáját neveltem fel az eszméért rajongani, áldozni és dolgozni tudó munkatársaknak. Még azon munkatársak sem veszítették el idealizmusukat, akik velem öregedtek meg.” 